\title{
ANALISIS PENERAPAN PENGENDALIAN INTERNAL PENERIMAAN KAS DARI PIUTANG USAHA PADA PT. TOMPOTIKA RAYA
}

\author{
Dewi Mahmuda \\ Program Studi Akuntansi, Fakultas Ekonomi \\ Universitas Muhammadiyah Buton, Baubau, Indonesia \\ Email: dwmahmuda@gmail.com
}

\begin{abstract}
ABSTRAK
Penelitian ini bertujuan untuk menganalisis penerapan pengendalian internal penerimaan kas dari piutang usaha padaPT. Tompotika Raya.Metode analisis data menggunakan metode kualitatif.Metode pengumpulan data menggunakan metode dokumentasi, observasi dan wawancara. Hasil penelitian menunjukkan bahwa secara umum pengendalian internal penerimaan kas dari piutang usaha pada PT. Tompotika Raya sudah cukup efektif.Hal ini terbukti dengan adanya pemisahan fungsisehingga transaksi yang terkait penerimaan kas dari piutang usaha tidak dilakukan oleh satu fungsi saja.Selain itu, pengendalian ingternal yang efektif juga terbukti dengan pemakaian dokumen dan catatan akuntansi yangmemadai yang diselenggarakan oleh karyawan berwenang dan juga jaringanprosedur yang berjalan dengan baik.
\end{abstract}

\section{Kata Kunci: Pengendalian Internal, Kas, Piutang Usaha}

\section{ABSTRACT}

This study aims to analyze the application of internal control cash receipts from accounts receivable at PT. Tompotika Raya. Data analysisusing qualitative methods.Data collection using the documentation, observation and interview. The results showed that in general the internal control of cash receipts from trade receivables at PT. Tompotika Raya is quite effective. This is evidenced by the separation of functions so that transactions related to cash receipts from trade receivables are not performed by a single function only. In addition, effectivityof internal control is also evidenced by the use of adequate document and accounting records held by authorized personnel as well as a network of procedures that work well.

Keywords:Internal Control, Cash, Accounts Receivable 


\section{Pendahuluan}

Suatu aset yang paling likuid pada perusahaan adalah kas. Kas adalah salah satu unsur terpenting dalam laporan keuangan, karena keterlibatannya hampir dalam setiap tramsaksi perusahaan [1]. Dilihat dari sifatnya kas merupakan aset yang paling lancar dan hampir setiap transaksi perusahaan selalu mempengaruhi kas. Kas merupakan komponen penting dalam kelancaran jalannya kegiatan operasional perusahaan. Karena sifatnya yang likuid, maka kas mudah digelapkan sehingga diperlukan pengendalian intern terhadap kas dengan memisahkan fungsi-fungsi penyimpanan, pelaksanaan dan pencatatan. Tanpa adanya pengendalian internal terhadap kas, maka akan mudah terjadi penggelapan kas [2].

Pencatatan kas yang baik tentulah tidak terlepas dari pengawasan dan pengendalian intern. Pengendalian intern sangat dibutuhkan dalam setiap aspek yang ada dalam perusahaan, terutama pengendalian intern atas penerimaan kas. Perjalanan sebuah sistem penerimaan kas membutuhkan prosedur yang mendukung yang harus dijalankan sesuai dengan kebutuhan dan aturan perusahaan. Prosedur yang dijalankan haruslah sesuai agar tidak terjadi tumpangtindih dalam segala aspek operasional perusahaan [3].

Suatu perusahaan yang berkembang semakin besar dalam menjalankan kegiatan usahanya memerlukan pengawasan yang semakin besar pula secara langsung terhadap jalannya operasi perusahaan. Pengawasan secara langsung diperlukan adanya wewenang kepada bawahan, namun tanggungjawab tetap berada pada pimpinan perusahaan. Oleh karena itu, untuk menghadapi semakin besarnya kegiatan suatu perusahaan atau bertambahnya transaksi yang terjadi, maka diperlukan adanya pengendalian intern yang baik demi menjaga efisiensi dan efektivitas suatu perusahaan dalam mencapai tujuannya [4].

Pengendalian intern adalah seperangkat kebijakan dan prosedur untuk melindungi asset perusahaan dari segala bentuk tindakan penyalahgunaan, menjamin tersedianya informasi akuntansi perusahaan yang akurat, serta memastikan bahwa semua ketentuan (peraturan) hukum atau Undang-Undang serta kebijakan manajemen tidak dipatuhi atau dijalankan sebagaimana mestinya oleh seluruh karyawan perusahaan [5] 
Pengendalian intern atas penerimaan kas dan penagihan piutang sangatlah penting, mengingat kas dan piutang usaha merupakan aktiva lancar yang sangat menarik dan mudah diselewengkan oleh para pejabat dan karyawan perusahaan,yang penggunaannya seringkalitidak sesuai dengan tujuan dan ketentuan yang telah ditetapkan perusahaan,sehingga menimbulkan pemborosan dan penyalahgunaan atas kas dan piutang tersebut. Oleh karena itu, kas dan piutang harus diawasi dengan benar, demi meyakinkan bahwa saldo kas dalam neraca benar-benar ada. Mengingat pentingnya kedudukan kedua aktiva lancar tersebut, maka manajemen membutuhkan suatu pengendalian intern yang dapat mengamankan aktivitas penerimaan kas dan penagihan piutang usaha. Piutang usaha adalah tagihan perusahaan kepada pihak lain yang nantinya akan dimintakan pembayarannya jika sudah sampai pada waktunya [6].

Pengendalian intern yang baik pada kas umumnya dicapai melalui pemisahan tugas dan pemisahan wewenang sehingga seseorang dapat melaksanakan suatu transaksi pada kas dan piutang usaha yang lengkap dari awal sampai akhir. Dengan adanya pemisahan tersebut akan memudahkan bagi manajemen untuk mengadakan penilaian dan pengambilan keputusan yang telah dilimpahkan pada masing-masing karyawan. Kesalahan pencatatan dalam penerimaan kas dan penagihan piutang memang biasa terjadi, untuk menghindari dan mencegah kebiasaan buruk ini agar tidak terjadi terus-menerus maka perlu dijaga pengendalian intern atas penerimaan kas dan penagihan piutang usaha, mulai dari pengawasan atas prosedur penagihan piutang, penerimaan kas sampai pada pencatatan kas tersebut. Hal ini dilakukan agar efektivitas pengendalian intern atas penerimaan kas dapat terus berlangsung [4].

Penerimaan kas yang mengikuti prosedur dan sesuai dengan aturan perusahaan akan menjadikan perusahaan menjadi lebih terkendali. Begitu pula dengan penagihan piutang dengan cara yang benar dan dengan pengawasan yang tepat menjadikan perusahaan lebih efektif dalam mengelola sumber pendapatan perushaaan. Oleh karena itu, penggunaan prosedur penerimaan kas yang baik dan tepat guna akan mempengaruhi keefektifan pengendalian intern perusahaan untuk menghindari kecurangan yang mungkin terjadi. 
Pengendalian internal atas penerimaan kas dan penagihan piutang sangatlah penting mengingat keduanya merupakan komponen aktiva lancar perusahaan yang sangat menarik dan mudah diselewengkan oleh para pejabat dan karyawan perusahaan,yang penggunaannya seringkalitidak sesuai dengan tujuan dan ketentuan yang telah ditetapkanperusahaan,sehingga menimbulkan penyalahgunaan atas kas dan nilai piutang tersebut. Oleh karena itu, perlu adanya pengendalian internal atas penerimaan kas dan piutang usaha dalam suatu perusahaan.

Melihat betapa pentingnya pengendalian internal dalam suatu perusahaan, khususnya terkait penerimaan kas dan penagihan piutang yang mana kedua aktiva tersebut merupakan aktiva paling likuid dan rentan penyalahgunaan, maka penelitian ini akan focus pada pengendalian internal kedua aktiva tersebut. Dengan demikian masalah dalam penelitian ini adalah bagaimana penerapan pengendalian internal penerimaan kas dari piutang usaha pada PT. Tompotika Raya?.

\section{METODE PENELITIAN}

\section{Populasi dan Sampel}

Populasi adalah wilayah generalisasi yang terdiri atas objek/subjek yang mempunyai kualitas dan karakteristik tertentu yang ditetapkan oleh peneliti untuk dipelajari kemudian ditarik kesimpulan [7]. Populasi dalam penelitian ini adalah pengendalian internal yang digunakan dalam kegiatan operasional PT. Tompotika Raya. Sampel adalah bagian dari populasi yang memiliki cirri-ciri atau keadaan tertentu yang akan diteliti [8]. Sampel penelitian ini adalah pengendalian internal penerimaan kas dari penagihan piutang usaha pada PT. Tompotika Raya Tahun 2016.

\section{Jenis dan Sumber Data}

Jenis data yang digunakan dalam penelitian ini adalah data kualitatif dan data kuantitatif. Dalam penelitian ini yang termasuk data kualitatif yaitu gambaran umum obyek penelitian, meliputi: Sejarah singkat berdirinya, letak geografis obyek, Visi dan Misi, struktur organisasi, dan lain-lain.Untuk data kuantitatif adalah jenis data yang dapat diukur atau dihitung secara langsung, yang berupa informasi atau penjelasan yang dinyatakan dengan bilangan atau berbentuk angka [7]. 


\section{Sumber Data}

Sumber data yang digunakan dalam penelitian ini adalah data primer dan data sekunder.

Data primer adalah data penelitian yang diperoleh langsung dari objek yang diteliti tanpa menggunakan perantara [9]. Data primer dalam penelitian ini adalah perangkat atau karyawan PT. Tompotika Raya. Sedangkan data sekunder adalahdata yang tidak diperoleh secara langsung oleh peneliti tetapi diperoleh dari orang orang atau pihak lain, misalnya berupa dokumen laporan-laporan [7].

\section{Metode Pengumpulan Data}

Data dalam penelitian ini dikumpulkan dengan metode observasi, dokumentasi, wawancara, dan kuisioner.Observasi dalam penelitian ini dilakukan dengan mengamati dan mencatat langsung kegiatan-kegiatan yang terkait dengan pengendalian internal penerimaan kas dan penagihan piutang usaha pada PT. Tompotika Raya.

Metode dokumentasi menurut [10] adalah informasi yang berasal dari catatan penting baik dari lembaga atau organisasi maupun dari perorangan. Data yang dikumpulkan melalui metode ini meliputi laporan penjualan, laporan penerimaan kas, laporan pemesanan pelanggan, dan lain-lain.Wawancara dilakukan dengan manajer, bagian penjualan, bagian pemenerimaan pesanan, bagian penagihan, dan kasir pada PT. Tompotika Raya. Peneliti menggunakan wawancara tidak terstruktur sebab peneliti tidak menggunakan pedoman wawancara atau secara sistematis, pedoman peneliti berupa garis-garis besar permasalahan yang ada di PT. Tompotika Raya.

\section{Metode Analisis Data}

Metode analisis yang digunakan dalam penelitian ini adalah analisis deskriptif kualitatif. Menurut Sugiyono (2010:25) analisis deskriptif kualitatif yaitu dengan memberikan ulasan atau interpretasi terhadap data yang diperoleh sehingga menjadi lebih jelas dan bermakna dibandingkan dengan sekedar angka-angka.

\section{HASIL DAN PEMBAHASAN}

\section{Hasil Penelitian}

Dalam menjalankan kegiatan usahanya PT. Tompotika Raya melaksanakan sistem penjualan secara tunai dan kredit. Untuk mengetahui pengendalian internal pada PT. 
tompotika Raya, peneliti melakukan wawancara dengan salah satu karyawan perusahaan tersebut yang bernama Bapak Akmal.Bapak Akmal bertugas di bagian penjualan perusahaan, yang membawahi bagian gudang dan bagian pengantaran. Berikut ini pernyataan Bapak Akmal tentang proses penjualan kredit pada PT. tompotika Raya.

"Proses penjualan kredit di sini dimulai dari pelanggan melakukan pesanan atau order kepada kami. Pesanannya berisi informasi produk seperti jumlah yang dipesan berapa banyak, jenis produknya apa saja, alamat pembeli di mana, dan kapan akan diantar.Karena ini menggunakan sistem pengantaran, biasanya jumlah barang yang dipesan pelanggan itu dalam partai besar sehingga membutuhkan alat angkut untuk produk tersebut bisa diterima oleh pelanggan" (Rabu, 6 September 2017).

Dari penyataan tersebut diketahui bahwa penjualan kredit yang dilakukan oleh PT. Tompotika Raya diberikan atas permintaan dari pelanggan yang biasanya pembelian dalam jumlah besar. Setelah menerima order dari pelanggan dan disetujui, perusahaan mengirimkan barang atau pelanggan mengambil sendiri sesuai dengan order dari pelanggan dan untuk jangka waktu tertentu.

Peneliti kemudian bertanya mengenai proses pembayaran atau pelunasan atas transaksi penjualan kredit yang terjadi di PT. Tompotika Raya. Bapak Akmal kembali menjawab:

"Karena penjualan tadi terjadi secara kredit, artinya pelanggan memesan lalu diantar sesuai waktu yang ditetapkan, maka biasanya pembayarannya itu tertunda untuk beberapa waktu tertentu. Pelanggan kami memang lokasinya kebanyakan berada di luar Kota Baubau sehingga proses pelunasannya bisa memakan waktu. Untuk pelanggan yang ingin melunasi utangnya ke prusahaan, bisa langsung membayar ke kasir perusahaan atau melalui transfer antar bank ke rekening yang sudah dirujuk perusahaan.(Rabu, 6 September 2017).

Pertanyaan selanjutnya tentang kebijakan perusahaan terkait pelanggan yang tidak tepat waktu dalam melunasi utangnya pada perusahaan. Bapak Akmal menjawab bahwa:

"Kami di perusahaan sudah punya daftar pelanggan dan jumlah transaksi yang mereka lakukan dengan kami.Biasanya pelanggan-pelanggan tersebut adalah pelanggan tetap perusahaan, sehingga catatan pembelian dan pelunasan dari mereka sudah banyak. Sampai sekarang pelanggan-pelanggan kami cukup bisa diajak kerja sama tentang pelunasan piutang ini, apalagi untuk pelanggan yang sudah lama bekerja sama dengan kami, itu biasanya sudah ada kepercayaan di dalamnya. Jadi ketika kami telepon untuk ingatkan batas pelunasan utang mereka, langsung saat itu 
juga mereka lakukan konfirmasi. Kalaupun terlambat hanya 1 atau 2 hari saja, hanya karena masalah ganggung jaringan transfer rekening atau kendala perjalanan ke perusahaan kami" . (Rabu, 6 September 2017).

Pertanyaan selanjutnya adakah sanksi atau denda yang diberikan oleh perusahaan kepada pelanggan yang tidak tepat waktu melunasi utangnya ke perusahaan. Bapak Akmal menjelaskan bahwa:

"Iya, ada perlakuannya untuk pelanggan-pelanggan nakal tersebut.Misalnya untuk transaksi berikutnya kami tidak izinkan lagi untuk membeli dalam jumlah partai yang besar, intinya dikurangi jumlahnya.Tapi sejauh ini catatan pelunasan pelanggan masih bisa diatasi oleh perusahaan, belum sampai kasih sanksi yang bisa mengganggu hubungan antara kami perusahaan dengan para pelanggan tersebut." (Rabu, 6 September 2017).

Dari penjelasan tersebut diketahui bahwa dalam melakukan pelunasan piutang pelanggan dapat membayar langsung ke perusahaan melalui bagian kasir atau mentransfer uang melalui bank yang telah mendapatkan kuasa dari perusahaan. Bagi pelanggan yang melanggar kesepakatan penjualan kredit, maka perusahaan akan memberikan denda kepada pelanggan. Denda tersebut sesuai dengan kesepakatan yang telah dibuat perusahaan dengan pelanggan, biasanya pembatasan pengajuan permintaan pembelian secara kredit oleh pelanggan kepada perusahaan.

Dari hasil observasi yang dilakukan oleh peneliti, maka diperoleh gambaran bahwa unsur-unsur terkait yang mendukung sistem penerimaan kas dari piutang usaha pada PT. Tompotika Raya adalah:

a. Fungsi yang terkait dalam penerimaan kas dari piutang usaha PT. Tompotika Raya pada PT. Tompotika Raya

1) Fungsi Penjualan

Dalam transaksi penjualan kredit pada PT. Tompotika Raya, fungsi pemasaran dilaksanakan oleh bagian pemasaran. Fungsi pemasaran bertanggung jawab menerima order dari pelanggan, meminta otorisasi kredit, membuat back order apabila barang yang dipesan pelanggan tidak tersedia di gudang.

2) Fungsi Gudang

Fungsi gudang dalam transaksi penjualan kredit pada PT. Tompotika Raya dilaksanakan oleh bagian gudang.Fungsi ini bertanggung jawab menyimpan 
dan menyiapkan barang apabila ada pesanan dari pelanggan kemudian menyerahkan barang kepada bagian pengiriman.

3) Fungsi Pengiriman

Fungsi pengiriman dalam PT. Tompotika Raya memegang peranan penting dalam aktivitas bisnis perusahaan.Fungsi pengiriman dalam transaksi penjualan kredit pada PT. Tompotika Raya dilaksanakan oleh bagian pengiriman. Fungsi pengiriman bertanggung jawab menyerahkan barang kepada pelanggan sesuai dengan order dari pelanggan dan surat pesanan yang dibuat oleh bagian penjualan. Fungsi pengiriman juga bertanggung jawab memastikan keamanan barang yang keluar dari perusahaan telah mendapatkan otorisasi dari bagian yang berwenang.

4) Fungsi Penerimaan Kas

Fungsi ini bertanggung jawab menerima uang pelunasan piutang pelanggan dari bagian pengiriman dan melakukan konfirmasi ke bagian akuntansi mengenai pelunasan tersebut.

5) Fungsi Akuntansi

Fungsi akuntansi pada PT. Tompotika Raya dilaksanakan oleh bagian akuntansi.Fungsi akuntansi dalam transaksi penjualan kredit bertugas melakukan pencatatan kedalam jurnal umum dan jurnal penjualan.Fungsi akuntansi bertanggung jawab untuk mencatat piutang yang timbul dari transaksi penjualan kredit dan membuat serta mengirimkan pernyataan piutang kepada para debitur.

b. Dokumen yang digunakan terkait penerimaan kas dari piutang usaha PT. Tompotika Raya

1) Memo

Memo dibuat oleh bagian penjualan saat menerima order dari pelanggan.

Memo ini berisi surat perintah kepada bagian gudang agar menyiapkan barang pesanan sesuai klasifikasi dan jumlah yang tertera dalam memo.

2) Surat Jalan

Dokumen ini dibuat oleh bagian gudang setelah menerima memo dari bagian penjualan.Surat pengeluaran barang diotorisasi oleh bagian gudang, kemudian digunakan sebagai dasar pembuatan faktur penjualan kredit.Surat pengeluaran 
barang dibuat sebagai bukti bahwa bagian gudang telah mengeluarkan barang sesuai permintaan dalam memo yang dibuat oleh bagian penjualan.

3) Faktur Penjualan

Dokumen ini digunakan untuk merekam transaksi penjualan kredit. Faktur penjualan dibuat oleh bagian penjualan setelah menerima surat pengeluaran barang dari bagian gudang.

c. Catatan akuntansi yang digunakan terkait penerimaan kas dari piutang usaha PT. Tompotika Raya

1) Jurnal Umum. Catatan ini digunakan oleh bagian akuntansi untuk mencatat transaksi penjualan kredit. Jurnal umum dijadikan sebagai dasar untuk memposting transaksi ke dalam kartu stok barang.

2) Jurnal Penerimaan Kas dari Piutang Usaha Jurnal penerimaan kas adalah catatan akuntansi yang mencatat penerimaan kas dari pelunasan utang pelanggan akibat transaksi penjualan kredit oleh perusahan.

3) Kartu Gudang

Kartu gudang adalah catatan yang digunakan oleh bagian gudang untuk mencatat mutasi dan persediaan fisik barang yang disimpan dalam gudang.

4) Kartu Persediaan

Kartu persediaan merupakan catatan yang termasuk ke dalam buku pembantu yang digunakan untuk mencatat mutasi persediaan sesuai dengan rinciannya.

\section{5) Kartu Piutang}

Catatan ini dibuat oleh bagian penjualan untuk mencatat saldo piutang pelanggan sesuai dengan nama pelanggan. Catatan ini digunakan sebagai dasar dalam pemberian kredit.Jika seorang pelanggan sudah tidak memiliki piutang yang belum dibayar maka pelanggan berhak mendapat kredit dari perusahaan.

d. Prosedur yang membentuk sistem penerimaan kas dari piutang usaha pada PT. Tompotika Raya

1) Prosedur Penerimaan Pesanan

a) Bagian penjualan menerima order dari pelanggan secara langsung maupun melalui telepon. 
b) Bagian penjualan memeriksa saldo piutang pelanggan yang bersangkutan untuk mengetahui status kreditnya. Jika pelanggan masih memilki piutang yang belum dibayar maka pelanggan belum bisa mendapat kredit lagi, jika pelanggan sudah tidak memilki utang kepada perusahaan maka pelanggan berhak mendapat kredit. Akan tetapi persetujuan kredit juga dapat diberikan kepada pelanggan yang masih memiliki utang dengan persyaratan bahwa pelanggan termasuk dalam tingkatan pelanggan yang sangat baikdalam pelunasan utang karena tidak pernah jatuh tempo dalam melunasi utangnya.

c) Jika order telah disetujui maka bagian penjualan membuat memo sebanyak dua lembar. Lembar ke-1 diberikan ke bagian gudang dan lembar yang ke2 diarsip oleh bagian penjualan menurut tanggal.

2) Prosedur Penyiapan Barang

a) Bagian gudang membuat surat pengeluaran barang setelah menerima memo dari bagian penjualan. Surat pengeluaran barang dibuat sebanyak dua lembar. Lembar ke-1 diserahkan ke bagian penjualan. Lembar ke-2 diserahkan ke bagian akuntansi yang nantinya akan dijadikan sebagai dasar pencatatan. Bagian gudang akan melakukan pengeluaran barang hanya berdasarkan memo yang telah diotorisasi oleh bagian penjualan.

b) Bagian penjualan menerima surat pengeluaran barang dari bagian gudang.

c) Bagian penjualan membuat faktur sebanyak tiga lembar. Lembar ke-1 berwarna putih disimpan oleh bagian penjualan untuk membuat kartu piutang dan untuk membuat daftar piutang yang ditagih yang kemudian akan dikembalikan ke pelanggan saat pelunasan piutang. Lembar ke-2 berwarna kuning diserahkan ke bagian pengiriman yang nantinya akan diserahkan ke pelanggan bersama dengan barang yang dikirim dan diminta kembalisaat pelunasan piutang. Lembar ke-3 berwarna merah muda diserahkan ke bagian akuntansi sebagai dasar pencatatan ke dalam jurnal.

d) Bagian penjualan mengarsip surat pengeluaran barang menurut tanggal. 
3) Prosedur Pengiriman Barang

a) Bagian pengiriman menerima Faktur Penjualan Kredit (FPK) lembar ke-2 dari bagian penjualan.

b) Bagian pengiriman mengirimkan barang kepada pelanggan beserta Faktur Penjualan Kredit (FPK) lembar ke-2 yang nantinya akan ditukar dengan FPK lembar ke-1 saat pelunasan.

4) Prosedur Pencatatan Piutang

a) Bagian akuntansi membandingkan antara surat pengeluaran barang yang diterima dari bagian gudang dan faktur penjualan yang diterima dari bagian penjualan.

b) Jika telah sama maka bagian akuntansi mencatat transaksi tersebut ke dalam jurnal umum berdasarkan faktur penjualan kredit lembar ke-3.

c) Surat pengelaran barang diarsip menurut tanggal dan faktur diarsip menurut nomor.

5) Prosedur Penagihan

a) Bagian pengiriman menerima faktur lembar ke-1 dari bagian penjualan.

b) Jika pelanggan melunasi piutang, maka Faktur Penjualan Kredit (FPK) lembar ke-1 dibubuhi tanda lunas oleh bagian pengiriman sebagai bukti bahwa piutang telah dibayar oleh pelanggan.

c) Faktur Penjualan Kredit (FPK) lembar ke-1 yang telah dibubuhi tanda lunas diserahkan ke pelanggan.

d) Faktur Penjualan Kredit (FPK) lembar ke-2 yang dibawa oleh pelanggan kemudiandiserahkan kepada bagian pengiriman untuk kemudian ditindak lanjuti.

e) Bagian pengiriman menyerahkan Faktur Penjualan Kredit (FPK) lembar ke-2 ke bagian kasir beserta dengan uang pelunasan piutang untuk membuktikan bahwa piutang telah dibayar oleh pelanggan dan perusahaan telah menerima pelunasan tersebut.

f) Bagian kasir melakukan konfirmasi ke bagian akuntansi bahwa piutang telah dilunasi oleh pelanggan agar seegra dilakukan pencatatan dalam jurnal perusahaan. 


\section{Pembahasan}

\section{Pengendalian Internal Penerimaan Kas dari Piutang Usaha pada PT. Tompotika Raya}

Pengendalian internal penerimaan kas dari piutang usaha pada PT. Tompotika Raya dapat dilihat dari 3 (tiga) lingkungan pengendalian, yaitu struktur organisasi yang memisahkan tanggung jawab fungsional, sistem otorisasi dan prosedur pencatatan, serta praktik yang sehat dalam lingkungan bisnis PT. Tompotika Raya.

1) Struktur Organisasi yang Memisahkan Tanggung Jawab Fungsional Penerimaan kas dari piutang usaha melalui transaksi penjualan kredit PT. Tompotika Raya telah dilaksanakan oleh lebih dari satu fungsi yaitu fungsi penjualan, fungsi gudang, fungsi pengiriman dan fungsi akuntansi. Fungsi-fungsi tersebut dijalankan oleh bagian yang berbeda. Fungsi penjualan dijalankan oleh bagian penjualan, fungsi gudang dijalankan oleh bagian gudang, pengiriman dijalankan oleh bagian pengiriman dan fungsi akuntansi dijalankan oleh bagian akuntansi. Fungsi akuntansi terpisah dari fungsi penerimaan kas. Bagian akuntansi dan kas yang terpisah telah menjamin ketelitian, keandalan dan keakuratan catatan akuntansi yang dihasilkan.Pemisahan fungsi ini akan mencegah terjadinya manipulasi catatan piutang dengan cara lapping atau berulang-ulang. Fungsi penjualan terpisah dari fungsi akuntansi. Dengan adanya pemisahan fungsi tersebut maka catatan piutang dapat dijamin ketelitian dan keandalannya serta kekayaan perusahaan (piutang) dapat dijamin keamanannya. Pemisahan fungsi ini juga menghindari adanya manipulasi data akuntansi di perusahaan.

2) Sistem Otorisasi dan Prosedur Pencatatan

Persetujuan dimulainya kegiatan penjualan diwujudkan dalam bentuk otorisasi pada memo dari bagian penjualan.Bagian gudang hanya akan mengeluarkan barang setelah mendapat memo yang telah diotorisasi oleh bagian penjualan. Faktur Penjualan Kredit (FPK) dibuat oleh bagian penjualan setelah mendapat Surat Pengeluaran Barang dari bagian gudang. Pencatatan ke dalam jurnal umum didasarkan pada faktur penjualan kredit. Setiap pencatatan transaksi yang terjadi 
dalam perusahaan dilakukan oleh bagian akuntansi dengan mengarsip tembusan faktur penjualan.

3) Praktik yang Sehat

Penggunaan surat pengeluaran barang dan faktur penjualan kredit sudah bernomor urut tercetak dan penggunaannya didistribusikan kepada bagian-bagian yang terkait.

\section{Analisis Pengendalian Internal Penerimaan Kas dari Piutang Usaha pada PT. Tompotika Raya}

Peneliti melakukan analisis melalui 5 (lima) sisi pengendalian internal yang terkait dengan penerimaan kas dari piutang usaha pada PT. Tompotika Raya, yaitu analisis terhadap fungsi yang terkait, analisis terhadap dokumen yang digunakan, analisis terhadap catatan akuntansi yang digunakan, analisis terhadap prosedur, dan analisis terhadap sistem pengawasan perusahaan.

1) Analisis Fungsi yang Terkait dengan Penerimaan Kas dari Piutang Usaha pada PT. Tompotika Raya. Pada PT. Tompotika Raya, fungsi yang terkait dalam sistem penerimaan kas dari piutang usaha terdiri dari fungsi penjualan, fungsi gudang, fungsi pengiriman, fungsi penerimaan kas dan fungsi akuntansi. Secara garis besar, pada PT. Tompotika Raya sudah terdapat pemisahan tiga fungsi utama, yaitu: fungsi operasi, fungsi penyimpanan, dan fungsi pencatatan. Tetapi juga masih terdapat perangkapan fungsi.Hal ini dikarenakan untuk meminimalisasi biaya operasional perusahaan.Perangkapan fungsi terdapat pada fungsi penjualan yang juga bertugas sebagai fungsi kredit dan fungsi pengiriman yang juga bertugas sebagai fungsi penagihan. Fungsi kredit yang dirangkap oleh fungsi penjualan, jika dalam pelaksanaannya tidak disertai dengan pengendalian tersendiri dari perusahaan maka perangkapan fungsi ini akan menimbulkan masalah seperti terdapat piutang tak tertagih yang jumlahnya cukup material. Hal ini disebabkan karena bagian penjualan menginginkan target penjualan sebanyak-banyaknya sehingga kurang teliti dalam hal menganalisis pemberian kredit kepada pembeli.

Sama halnya dengan perangkapan fungsi penjualan, fungsi pengiriman yang juga merangkap sebagai fungsi penagihan juga memiliki risiko, risikonya adalah 
penggelapan uang hasil tagihan.Risiko perangkapan fungsi pengiriman dan fungsi penagihan tadi sudah diantisipasi dengan sebuah tindakan pengendalian, yaitu uang hasil tagihan harus disetorkan ke bagian kasir setiap jam kerja berakhir dengan menggunakan dokumen-dokumen yang berlaku.

2) Analisis terhadap Dokumen yang Digunakan dalam Penerimaan Kas dari Piutang Usaha pada PT. Tompotika Raya. Dokumen yang digunakan meliputi memo, surat pengeluaran barang dan faktur penjualan. Pada PT. Tompotika Raya, memo mempunyai fungsi yang sama dengan surat order pengiriman. Memo ini akan diberikan kepada bagian gudang sebagai dasar pembuatan surat pengeluaran barang. Surat pengeluaran barang akan diberikan ke bagian penjualan yang akan dijadikan sebagai dasar pembuatan faktur penjualan. Faktur penjualan dibuat sebanyak tiga rangkap yang masing-masing akan didistribusikan ke bagian akuntansi sebagai dasar pencatatan transaksi dan ke pembeli. Dokumen-dokumen tersebut telah mendapat otorisasi dari bagian yang berwenang, sehingga data-data yang berhubungan dengan penjualan kredit dapat dipertanggungjawabkan.

3) Analisis terhadap Catatan Akuntansi yang Digunakan dalam Penerimaan Kas dari Piutang Usaha pada PT. Tompotika Raya. Catatan akuntansi yang digunakan meliputi jurnal umum, kartu stok barang, dan kartu piutang. Catatan tersebut diselenggarakan oleh bagian terkait, sesuai dengan terjadinya transaksi penjualan kredit. Pencatatan transaksi dilakukan atas dasar dokumen sumber yang nantinya akan menghasilkan catatan akuntansi yang akurat. Misalnya catatan akuntansi yang berupa jurnal umum dibuat atas dasar faktur penjualan. Catatan akuntansi tersebut akan dijadikan sebagai dasar pelaporan kepada bagian keuangan kantor pusat.

Bagian akuntansi pada PT. Tompotika Raya hanya melakukan pencatatan secara sederhana untuk memudahkan dalam hal mereview hasil penerimaan dan pengeluaran.Secara garis besar catatan yang diselenggarakan oleh bagian akuntansi telah cukup memadai.

4) Analisis terhadap Prosedur Penerimaan Kas dari Piutang Usaha pada PT. Tompotika Raya. Prosedur yang dilaksanakan oleh PT. Tompotika Raya sudah cukup baik. Hal ini dimulai dengan prosedur order penjualan, prosedur penyiapan 
barang, prosedur pengiriman, prosedur pencatatan piutang, dan prosedur penagihan piutang. Bagian yang terkait dalam sistem penjualan kredit tidak terpusat pada satu bagian tetapi telah dibagi dalam beberapa bagian. Namun ada beberapa prosedur yang dijalankan oleh bagian yang sama, yaitu prosedur penjualan dan prosedur persetujuan kredit ditangani oleh satu bagian yakni bagian penjualan. Begitu pula prosedur pengiriman dan prosedur penagihan juga ditangani oleh satu bagian yakni bagian pengiriman.Hal ini dimaksudkan untuk meminimalisasi biaya operasional perusahaan.

\section{KESIMPULAN}

Kesimpulan yang diperoleh dari hasil penelitian ini adalah secara umum pengendalian internal penerimaan kas dari piutang usaha pada PT. Tompotika Raya sudah cukup efektif.Hal ini terbukti dengan adanya pemisahan fungsisehingga transaksi yang terkait penerimaan kas dari piutang usaha tidak dilakukan oleh satu fungsi saja.Selain itu, pengendalian internal yang efektif juga terbukti dengan pemakaian dokumen dan catatan akuntansi yangmemadai yang diselenggarakan oleh karyawan berwenang sertaprosedur yang berjalan dengan baik.Struktur organisasi yang dibuat oleh perusahaan memisahkan tanggung jawabsecara tegas fungsi setiap bagian, sistemwewenang dan otorisasi oleh bagian terkait, praktik yang sehat dalammelaksanakan tugas serta karyawan yang mutunya sesuai dengan tanggungjawabnya

\section{SARAN}

Saran peneliti yang dapat dijadikan masukan bagi perusahaan untuk memperbaiki sistem yang sudah ada, yaitu:Sebaiknya fungsi kredit,fungsi penjualan,fungsi penagihan,dan fungsi pengiriman dilaksanakan oleh bagian yang berbeda.Hal ini bertujuan untuk menjamin piutang dapat ditagih seluruhnya, sehingga dapat meminimalisir kemungkinan terjadinya piutang tak tertagih serta untuk menghindari penggelapan uang hasil tagihan piutang. Sebaiknya perusahaan memberikan pelatihan kepada karyawan untuk meningkatkan kualitas demi menunjang kinerja perusahaan. 


\section{DAFTAR PUSTAKA}

[1] Santoso, Iman. 2007. Akuntansi Keuangan Menengah (Intermediate Accounting). Cetakan Pertama. Bandung : PT. Refika Aditama.

[2] Agoes, Sukrisno. 2012. Auditing: Petunjuk Praktis Pemeriksaan Akuntan oleh Akuntan Publik. Edisi Keempat. Jakarta: Salemba Empat.

[3] Syakur, S.A. 2009. Intermediate Accounting Dalam Perspektif Lebih Luas. Cetakan Pertama. Yogyakarta : CAPS.

[4] Mulyadi. 2010. Sistem Akuntansi Edisi Ketiga. Yogyakarta:Salemba Empat.

[5] Hery, 2013. Auditing (Pemeriksaan Akuntansi 1). Cetakan Pertama. Jakarta : Grasindo.

[6] Munandar. M. 2006. Pokok-pokok Intermediate Accounting. Cetakan ke-2. Edisi Keenam. Yogyakarta : Gadjah Mada University Press.

[7] Sugiyono. 2010. Metode Penelitian Kuantitatif, Kualitatif dan R\&D. Bandung: Alfabeta

[8] Martono, Nanang. 2010. Metode Penelitian Kuantitatif : Analisis Isi dan Analisis Data Sekunder. Edisi 1. Cetakan Ke-1. Jakarta : PT. Raja Grafindo Persada.

[9] Soewadji, Jusuf. 2012. Pengantar Metodologi Penelitian, Jilid 1. Jakarta : Mitra Wacana Media.

[10] Hamidi, 2004. Metode Penelitian Kualitatif. Aplikasi Praktis Pembuatan Proposal dan Laporan Penelitian. 